\title{
Article \\ Study Regarding the Micro Filler Effect of Sludge Resulting from Steel Pickling
}

\author{
Claudiu Aciu ${ }^{1}$, Daniela Lucia Manea ${ }^{1}$ and Dana-Adriana Iluţiu-Varvara ${ }^{2, *}$ \\ 1 Faculty of Civil Engineering, Technical University of Cluj-Napoca, 28 Memorandumului Street, \\ 400114 Cluj-Napoca, Romania; claudiu.aciu@ccm.utcluj.ro (C.A.); Daniela.Manea@ccm.utcluj.ro (D.L.M.) \\ 2 Faculty of Building Services Engineering, Technical University of Cluj-Napoca, 28 Memorandumului Street, \\ 400114 Cluj-Napoca, Romania \\ * Correspondence: dana.varvara@gmail.com or dana.adriana.varvara@insta.utcluj.ro
}

check for updates

Citation: Aciu, C.; Manea, D.L.;

Iluţiu-Varvara, D.-A. Study

Regarding the Micro Filler Effect of Sludge Resulting from Steel Pickling. Metals 2021, 11, 361. https:// doi.org/10.3390/met11020361

Academic Editors: Fernando Castro and Hary Demey

Received: 29 December 2020

Accepted: 18 February 2021

Published: 21 February 2021

Publisher's Note: MDPI stays neutral with regard to jurisdictional claims in published maps and institutional affiliations.

Copyright: (C) 2021 by the authors. Licensee MDPI, Basel, Switzerland. This article is an open access article distributed under the terms and conditions of the Creative Commons Attribution (CC BY) license (https:// creativecommons.org/licenses/by/ $4.0 /)$.

\begin{abstract}
The management of waste, resulting in high amounts from different production processes, often raises special problems. This is also the case for sludge, generated in increasing amounts from the chemical pickling of steel pipes. This article presents the results of laboratory experiments regarding the micro filler effect of sludge generated by chemical pickling of steel pipes and analyzes its capacity to be a pozzolanic material. The study involved the performance of mechanical tests (specific surface of the powder; compressive mechanical strengths) and chemical tests (determination of the general chemical composition of cement and sludge using the X-ray fluorescence (XRF) method; determination of oxides in the chemical composition of sludge by Inductively Coupled Plasma Optical Emission Spectroscopy (ICP-OES); X-ray diffraction (XRD) analysis of the sludge and cement used). This topic was addressed because recycling of sludge, by using it for the manufacture of new building materials, takes advantage of the waste resulting from the pickling of steel pipes that-until now-has generated large volumes without a specific use.
\end{abstract}

Keywords: building materials; metallurgical waste; mortar; recycling; sludge; sustainable steel industry; waste management

\section{Introduction}

Under sustainable development conditions in the field of construction, researchers' attention has focused on the manufacture of new ecological building materials.

Many researchers have focused on utilizing different industrial by-products in the production of sustainable, ecological cement and concrete [1,2].

Portland cement is a binding material which provides very good mechanical characteristics compared with several other materials. The worldwide production of cement amounts to almost $5 \mathrm{Gt}$. Due to the high calcination temperature, the production of cement requires significant energy inputs, being responsible for almost $10 \%$ of worldwide $\mathrm{CO}_{2}$ emissions [3].

The increased use of industrial wastes and by-products as supplementary cementitious materials to produce concretes and blended cements represents a way to obtain net zero $\mathrm{CO}_{2}$ emissions [4].

Incorporating a wide range of wastes (wood-based fly ash, wheat straw ash, granite sawdust waste, palm oil fuel ash etc.) as cement substitutes in concrete might, in addition to improving mechanical properties and durability, favor the removal of noxious materials and prevent massive amounts of waste being deposited in the environment [5-11].

It is necessary to search for other materials susceptible to activation for use as active pozzolans in cementitious systems. A pozzolanic material is generally defined as a natural, synthetic, or secondary raw material, containing high percentages of active $\mathrm{SiO}_{2}$ and $\mathrm{Al}_{2} \mathrm{O}_{3}$ [12-16]. 
According to Sicakova and Spak, mineral additives may be categorized as followschemically active mineral admixtures (highly reactive pozzolan) and micro-filler mineral additives (low to moderately reactive pozzolan). The character depends on the physical (particle size, particle shape, specific surface area, etc.) and chemical properties (chemical and mineralogical/phase composition, ratio of hydraulic oxides); the source from and process by which these components are obtained are responsible for the particular character [17].

Metal waste recovery plays a key role in the task of complying with the ambitious environmental objectives set by the European Union, with a significant impact on greenhouse gas emissions and, therefore, on global climate change.

The European Union finances some significant projects aiming to provide energy and resource flexibility to energy intensive industries (the CIRMET Project - Innovative and efficient solution, based on modular, versatile, smart process units for energy and resource flexibility in highly energy intensive processes) and to study the possibilities of processing metals and recovering metal wastes in a more sustainable way (the DIGISER++ project Innovative waste recycling for the copper industry) [18,19].

Industrial by-products and waste result from different industrial processes, such as the steel manufacturing process. In steel industry, by-products are represented by steel slag.

The surface treatments of steel, such as pickling, involve cleaning to remove oxides, mill scale and dust. This process is performed by hot immersion in acid solution. The evacuated baths are treated by chemical methods and the quality of effluents should be ensured in accordance with the standards.

The treatment methods involve precipitation of heavy metals, flocculation, sedimentation and deposition. Each stage is conducted in a separate container and the entire process requires several $\mathrm{pH}$ adjustments, as well as coagulant and lime addition.

The process leads to the generation of high amounts of sludge, with a major environmental and economic impact. Currently, sludge-after neutralization-is stored in authorized external deposits. Due to the continuous increase in sludge amounts, as well as associated economic and environmental factors, solutions are searched to recover the neutralization sludge and to avoid its storage in deposits.

There are many methods for sludge management. It could be used in agriculture, building materials, wastewater treatment reagents, sludge dewatering or land filling [20-24]. Such methods, in addition to their advantages, economic savings, and environmental sustainability, have some limitations, such as the complexity of the method and problems that can be caused by the pollutants present in the sludge [22].

Ilutiu-Varvara et al. studied the possibility of using the metallurgical wastes (steel mill scales) in the composition of mortar. The recycling of the oily mill scale in mortar compositions is a form of sustainable manufacturing through the conservation of raw material [25].

Following the studies performed, ground granulated blast furnace slag was proven to have a pozzolanic and cement-like behavior, and is therefore being used in the composition of various types of cement [26-29]. In addition, there are a few studies regarding the use of steel sludge in concrete.

However, we refer to the study conducted by Nurul et al., regarding the performance of steel slag and sludge in concrete by evaluations of the pozzolanic activity [30]. The materials used in this study were: Portland cement type 1 according to the American Society for Testing and Materials (ASTM), steel slag, steel sludge, aggregates, and water.

While steel slag was obtained through the melting of metal residues in an electric arc furnace, steel sludge-referred to in the literature-was obtained from steel cable production, generated during the remodeling of cables to obtain the desired shape and size [30].

The results obtained by the mentioned team show that including both the slag and the sludge in the cement of concrete improves its compressive strength. Although 10\% slag addition seemed to be the optimal dose, adding a percentage of up to 15 and $20 \%$ 
of sludge and slag, respectively, induced a superior increase in strength compared to the control (standard) mixture, particularly at longer setting times (over 60 days) [30].

Concrete containing steel sludge showed improvements in the flexural strength. However, the development of the flexural strength, in the case of sludge in particular, was slow compared to that of the control (standard) mixture. Nevertheless, a percentage of up to $20 \%$ steel slag and 5\% steel sludge could be applied to cement without the risk of it affecting the flexural strength quality of the concrete [30].

The presence of oxides such as $\mathrm{CaO}, \mathrm{SiO}_{2}, \mathrm{FeO}$ and $\mathrm{Al}_{2} \mathrm{O}_{3}$ make metallurgical wastes useful as clinker materials in cement production [31].

This study aimed at investigating the sue of sludge as a possible addition to ordinary Portland cement in order to obtain a sustainable, ecological cement that takes advantage of the waste resulting from the pickling of steel pipes that, until now, has generated large volumes without a specific use.

\section{Materials and Methods}

"Structo Plus" cement type: CEM II/B-A1(S-LL) 42.5N, SR EN 197-1:2011 manufactured by Holcim (Alesd, Romania); steel sludge; sand with a grain size of up to $2 \mathrm{~mm}$, and water were used.

The CEM II/B-A1(S-LL) cement is a variant of CEM II/B-LL (SR EN 197) cement, which is a mixed cement: Portland with limestone, whose "main component (without a clinker) is limestone with organic carbon that does not exceed $0.2 \%$ (LL)", having the $42.5 \mathrm{~N}$ strength class.

The sludge samples were taken from a metallurgical plant, which produces different domestically made steel trademarks, located in Salaj County, Romania.

The plant produces cold drawn pipes from hot rolled tubes, which are pickled with sulfuric acid before being processed and finished. The waste generated from the pickling, are treated by precipitation of heavy metals, flocculation, sedimentation and deposition. Each stage is conducted in a separate container and the entire process requires several $\mathrm{pH}$ adjustments, as well as coagulant and lime addition. The process leads to the generation of high amounts of sludge.

In order for the sampling to be representative of the whole manufacturing process, a sample was taken once a week for twelve weeks and the resulting samples were merged in a homogenous sludge sample.

Initially, the sludge samples were in the form of plates of variable sizes, with a fragile consistency, which allowed them to be easily ground (Figure 1a).

These samples were dried in the oven at a temperature of $105^{\circ} \mathrm{C}$ and were subsequently ground. Grinding was performed in a ball mill, and a material with a fine grain size was obtained (Figure 1b).

After grinding, the sludge was sieved with a mesh of $0.125 \mathrm{~mm}$ (Figure 1c).

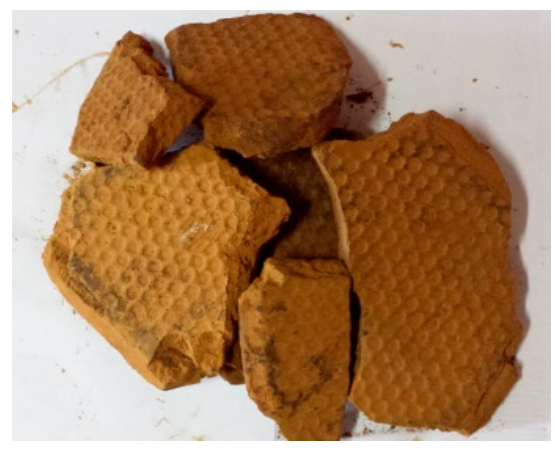

(a)

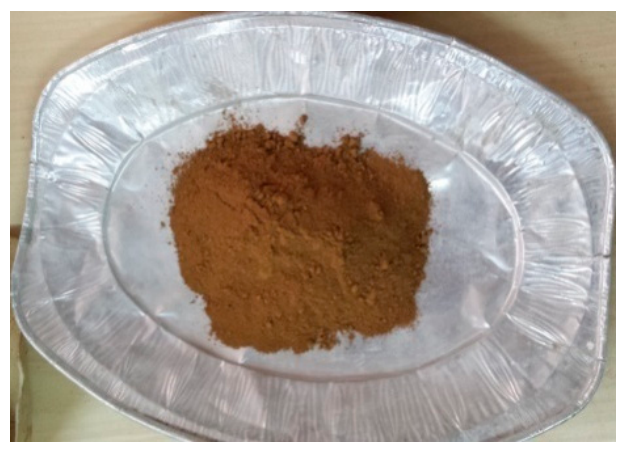

(b)

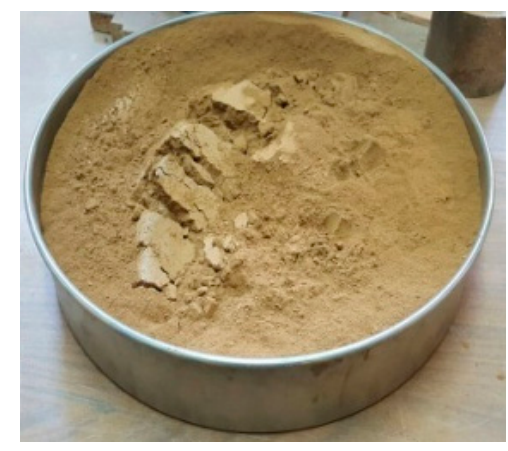

(c)

Figure 1. (a) Sludge sample; (b) Ground sludge; (c) Dried and sieved sludge. 
The resulting powder was analyzed for determination of its element content (\%), using the X-ray fluorescence (XRF) method, with an INNOV-X ALPHA 6500 analyzer, and for confirmation, with a simultaneous-detection inductively coupled plasma-optical emission spectrometer ICP-OES (SpectroFlame FMD 07, Kleve, Germany).

The chemical composition was also studied using the X-ray diffraction (XRD) method with a D8 ADVANCE analyzer-Da Vinci Design-manufacturer Bruker AXS GmbH, Karlsruhe, Germany.

The mix proportions in which in the composition of standard mortar (RS) cement is replaced by 10\% (R10C), 20\% (R20C), 30\% (R30C), and 40\% (R40C) steel sludge, respectively, are presented in Table 1.

Table 1. Mortar mix proportions for $1 \mathrm{~m}^{3}$ mortar.

\begin{tabular}{|c|c|c|c|c|c|c|c|}
\hline \multirow{2}{*}{ Mix Proportions } & \multirow{2}{*}{ Cement 42.5} & \multirow{2}{*}{ Water } & \multicolumn{4}{|c|}{ Sand } & \multirow{2}{*}{ Sludge } \\
\hline & & & $(0.08-0.16) \mathrm{mm}$ & $(0.16-0.5) \mathrm{mm}$ & $(0.5-1) \mathrm{mm}$ & $(1-2) \mathrm{mm}$ & \\
\hline Units & $(\mathrm{kg})$ & $\left(\mathrm{dm}^{3}\right)$ & $(\mathrm{kg})$ & $(\mathrm{kg})$ & $(\mathrm{kg})$ & $(\mathrm{kg})$ & $(\mathrm{kg})$ \\
\hline RS & 586.5 & 293.3 & 195.5 & 391.0 & 586.5 & 586.5 & 0.0 \\
\hline R10C & 527.9 & 293.3 & 195.5 & 391.0 & 586.5 & 586.5 & 58.6 \\
\hline R20C & 469.2 & 293.3 & 195.5 & 391.0 & 586.5 & 586.5 & 117.3 \\
\hline R30C & 410.6 & 293.3 & 195.5 & 391.0 & 586.5 & 586.5 & 176.0 \\
\hline $\mathrm{R} 40 \mathrm{C}$ & 351.9 & 295.9 & 195.5 & 391.0 & 586.5 & 586.5 & 234.6 \\
\hline
\end{tabular}

\subsection{The Methods for the Preparation of Mortar}

For the standard mix proportion, the classical method for the preparation of mortar was used, with a water/binder ratio of 0.5 .

The test pieces were made according to the standards in force [32]; the materials were weighed, homogenized with a mixer, and test pieces were made $\left(4 \times 4 \times 16 \mathrm{~cm}^{3}\right.$ prisms and $20 \times 20 \times 5 \mathrm{~cm}^{3}$ plates).

The consistency of the standard mortar was determined with the Tecnotest spreading mass (Treviolo, Italy), meeting the requirement of a spreading value of $175 \pm 10 \mathrm{~mm}$ for fresh mortar with an apparent density over $1200 \mathrm{~kg} / \mathrm{m}^{3}$.

\subsection{Analysis Methods}

For the evaluation of the pozzolanic activity of steel sludge, mechanical and chemical tests were performed. Mechanical tests consisted of:

- Determination of the specific surface of powder with a Blaine permeabilimeter [33];

- The determination of the compressive mechanical strengths was performed with the $250 \mathrm{KN}$ Tecnotest hydraulic press (Treviolo, Italy) [34].

Chemical tests consisted of:

- Determination of the general chemical composition of the cement and of the sludge by X-ray fluorescence (XRF) method with an INNOV-X ALPHA 6500 analyzer;

- Determination of oxides in the chemical composition of cement and sludge by Inductively Coupled Plasma Optical Emission Spectroscopy ICP-OES (SpectroFlame FMD 07, Kleve, Germany);

- Leaching test of the sludge by Inductively Coupled Plasma Mass Spectrometer Perkin Elmer type Elan DRC II (Perkin-Elmer, Toronto, ON, Canada);

- Determination of the mineralogical composition of sludge and cement, the X-ray diffraction (XRD) method was used with a D8 ADVANCE analyzer—Da Vinci Designmanufacturer Bruker AXS GmbH (Karlsruhe, Germany). 


\section{Results and Discussion}

\subsection{The Chemical Composition of Materials}

The general chemical composition of the cement and sludge was performed using the X-ray fluorescence (XRF) method with an INNOV-X ALPHA 6500 analyzer (Max Analyzer, Inc., Jakarta, Indonesia), and for the confirmation of the results, a simultaneous detection inductively coupled plasma-optical emission spectrometer ICP-OES was used (SpectroFlame FMD 07, Kleve, Germany).

In the general chemical composition of the cement and sludge, 69 elements were identified, of which, the most representative are presented in Tables 2 and 3, respectively.

Table 2. The chemical composition of cement using the XRF method.

\begin{tabular}{ccccccccccccc}
\hline Element & $\mathbf{C a}$ & $\mathbf{F e}$ & $\mathbf{Z n}$ & $\mathbf{S r}$ & $\mathbf{M n}$ & $\mathbf{P b}$ & $\mathbf{T i}$ & $\mathbf{B a}$ & $\mathbf{C u}$ & $\mathbf{R b}$ & $\mathbf{Z r}$ \\
\hline Units & $\%$ & $\mathrm{mg} / \mathrm{kg}$ & $\mathrm{mg} / \mathrm{kg}$ & $\mathrm{mg} / \mathrm{kg}$ & $\mathrm{mg} / \mathrm{kg}$ & $\mathrm{mg} / \mathrm{kg}$ & $\mathrm{mg} / \mathrm{kg}$ & $\mathrm{mg} / \mathrm{kg}$ & $\mathrm{mg} / \mathrm{kg}$ & $\mathrm{mg} / \mathrm{kg}$ & $\mathrm{mg} / \mathrm{kg}$ \\
Value & $>10$ & 12,312 & 412 & 354 & 952 & 29 & 1010 & 189 & 55 & 24 & 67 \\
Value $(\%)$ & $>10$ & 1.23 & 0.04 & 0.035 & 0.095 & 0.003 & 0.1 & 0.019 & 0.006 & 0.002 & 0.007 \\
\hline
\end{tabular}

Table 3. The chemical composition of sludge using the XRF method.

\begin{tabular}{cccccccccccc}
\hline Element & $\mathbf{C a}$ & $\mathbf{F e}$ & $\mathbf{Z n}$ & $\mathbf{S r}$ & $\mathbf{M n}$ & $\mathbf{C o}$ & $\mathbf{N i}$ & $\mathbf{M o}$ & $\mathbf{S i}$ & $\mathbf{A l}$ & $\mathbf{N a}$ \\
\hline Units & $\%$ & $\%$ & $\mathrm{mg} / \mathrm{kg}$ & $\mathrm{mg} / \mathrm{kg}$ & $\mathrm{mg} / \mathrm{kg}$ & $\mathrm{mg} / \mathrm{kg}$ & $\mathrm{mg} / \mathrm{kg}$ & $\mathrm{mg} / \mathrm{kg}$ & $\mathrm{mg} / \mathrm{kg}$ & $\mathrm{mg} / \mathrm{kg}$ & $\mathrm{mg} / \mathrm{kg}$ \\
Value & $>10$ & $>10$ & 16,513 & 37 & 2299 & 203 & 396 & 379 & 266 & 333 & 945 \\
Value $(\%)$ & $>10$ & $>10$ & 1.65 & 0.004 & 0.23 & 0.02 & 0.04 & 0.038 & 0.027 & 0.033 & 0.095 \\
\hline
\end{tabular}

An analysis of the chemical composition of the two materials showed that they have common elements: calcium, iron, zinc, strontium and manganese. In addition, cement contains: lead, titanium, barium, copper, rubidium and zirconium, and steel sludge contains: cobalt, nickel, molybdenum, silicon, aluminum and sodium. If calcium in both compositions represents more than $10 \%$ of all elements, iron in cement is low $(1.23 \%)$ compared to its proportion in the composition of sludge $(>10 \%)$. The same is true for manganese- $0.095 \%$ compared to $0.23 \%$, and zinc- $0.04 \%$ compared to $1.65 \%$.

It can be concluded that there is a great difference between the chemical compositions of the two materials.

For the environmental assessment of the waste, the leaching test of a sludge was performed using an Inductively Coupled Plasma Mass Spectrometer Perkin Elmer type Elan DRC II (Perkin-Elmer, Toronto, ON, Canada) according to EN ISO 17294-2:2016 [35,36]. The quality control was assured using a certified reference material NIST 1643e from NIST. The leaching values are presented in Table 4.

The results were compared with the leaching values provided by the council decision of 19 December 2002, establishing criteria and procedures for the acceptance of waste in landfills pursuant to Article 16 of and Annex II to Directive 1999/31/EC [37].

From Table 4 it can be concluded that this sludge does not have a negative environmental impact because, according to environmental legislation, the determined elements do not exceed the maximum allowable limits. 
Table 4. Leaching values for sludge using the ICP-MS.

\begin{tabular}{|c|c|c|c|c|}
\hline No. & Element & Units & Value & Limit Values \\
\hline 1 & $\mathrm{Al}$ & $\mathrm{mg} / \mathrm{kg}$ & 0.13 & - \\
\hline 2 & $\mathrm{Ba}$ & $\mathrm{mg} / \mathrm{kg}$ & 0.227 & 100 \\
\hline 3 & $\mathrm{Br}$ & $\mathrm{mg} / \mathrm{kg}$ & 0.128 & - \\
\hline 4 & $\mathrm{Ti}$ & $\mathrm{mg} / \mathrm{kg}$ & 1.033 & - \\
\hline 5 & $\mathrm{Cd}$ & $\mathrm{mg} / \mathrm{kg}$ & $\mathrm{BLQ}^{*}(<0.001)$ & 1 \\
\hline 6 & $\mathrm{Ca}$ & $\mathrm{mg} / \mathrm{kg}$ & 680 & - \\
\hline 7 & $\mathrm{Cr}$ & $\mathrm{mg} / \mathrm{kg}$ & BLQ $(<0.001)$ & 10 \\
\hline 8 & $\mathrm{Ni}$ & $\mathrm{mg} / \mathrm{kg}$ & 0.119 & 10 \\
\hline 9 & $\mathrm{Cu}$ & $\mathrm{mg} / \mathrm{kg}$ & 0.010 & 50 \\
\hline 10 & $\mathrm{Zn}$ & $\mathrm{mg} / \mathrm{kg}$ & 0.0545 & 50 \\
\hline 11 & As & $\mathrm{mg} / \mathrm{kg}$ & BLQ $(<0.001)$ & 2 \\
\hline 12 & $\mathrm{Sr}$ & $\mathrm{mg} / \mathrm{kg}$ & 3.5 & - \\
\hline 13 & $\mathrm{~Pb}$ & $\mathrm{mg} / \mathrm{kg}$ & BLQ $(<0.001)$ & 10 \\
\hline 14 & $\mathrm{Mn}$ & $\mathrm{mg} / \mathrm{kg}$ & 0.0146 & - \\
\hline 15 & $\mathrm{Hg}$ & $\mathrm{mg} / \mathrm{kg}$ & BLQ $(<0.001)$ & 0.2 \\
\hline 16 & Mo & $\mathrm{mg} / \mathrm{kg}$ & BLQ $(<0.001)$ & 10 \\
\hline 17 & $\mathrm{Fe}$ & $\mathrm{mg} / \mathrm{kg}$ & 0.947 & - \\
\hline 18 & $\mathrm{Na}$ & $\mathrm{mg} / \mathrm{kg}$ & 14.100 & - \\
\hline 19 & $\mathrm{Mg}$ & $\mathrm{mg} / \mathrm{kg}$ & 0.137 & - \\
\hline 20 & K & $\mathrm{mg} / \mathrm{kg}$ & 29.60 & - \\
\hline 21 & $\mathrm{Sb}$ & $\mathrm{mg} / \mathrm{kg}$ & BLQ $(<0.001)$ & 0.7 \\
\hline 22 & Se & $\mathrm{mg} / \mathrm{kg}$ & BLQ $(<0.001)$ & 0.5 \\
\hline
\end{tabular}

*BLQ—Values below the limit of quantification.

\subsection{Mechanical Tests}

The pozzolanic reaction rate is dependent on the intrinsic characteristics of the pozzolanic material, such as specific surface, chemical composition and active phase content.

\subsubsection{Grinding Fineness}

The sludge was ground using a ball mill, resulting in the production of a powder with a very fine grain size, which means that it had a large specific surface. This ensures a high pozzolanic activity, as explained by the creation of a larger surface area available for reaction. Furthermore, through grinding, crystallographic defects are created below the particle surface as well. The dissolution velocity of tensed or partially detached silicate fragments is significantly improved. Even materials that are not usually considered to behave in a manner similar to volcanic tuff, such as steel sludge, can become reactive below a certain critical diameter of the particle [38].

\subsubsection{Specific Surface of Particles}

The specific surface was determined using the Blaine permeabilimeter method [33], and the following were obtained:

- The specific surface of sludge grains $=11,370.58 \mathrm{~cm}^{2} / \mathrm{g}$

- $\quad$ The specific surface of cement grains $=3813.90 \mathrm{~cm}^{2} / \mathrm{g}$

As can be seen, the specific surface of sludge grains is almost three (2.98) times larger than that of cement grains.

In conclusion, the sludge can be reactive if the particle diameter has reached the critical size.

\subsubsection{Compressive Strength}

This test represents the evaluation of the pozzolanic activity of sludge by comparing the compressive strength of the mortar test pieces in which part of the Portland cement was replaced by sludge and the standard test piece containing only Portland cement. 
In the current case, four mortar mix proportions were prepared, by replacing 10, 20, 30 and $40 \%$ cement in the standard mortar mix proportion with steel sludge, as shown in to Table 1.

The mechanical test regarding the pozzolanic activity of steel sludge consists of analyzing the increase in the compressive strength of mortar after 28 days.

As shown in Table 5, the following evolution of the compressive strength of standard mortar can be seen: at 7 days, it reaches $20.63 \mathrm{~N} / \mathrm{mm}^{2}$, increasing at 28 days to the value of $25.98 \mathrm{~N} / \mathrm{mm}^{2}$ and reaching $29.28 \mathrm{~N} / \mathrm{mm}^{2}$ after 90 days.

Table 5. Comparative study of compressive strength over time.

\begin{tabular}{|c|c|c|c|}
\hline \multirow{2}{*}{ Mix Proportions } & \multicolumn{3}{|c|}{ Compressive Strength $\left(\mathrm{N} / \mathrm{mm}^{2}\right)$} \\
\hline & 7 Days & 28 Days & 90 Days \\
\hline RS & 20.63 & 25.98 & 29.28 \\
\hline $\mathrm{R} 10 \mathrm{C}$ & 12.32 & 18.64 & 23.88 \\
\hline $\mathrm{R} 20 \mathrm{C}$ & 12.79 & 20.10 & 20.68 \\
\hline $\mathrm{R} 30 \mathrm{C}$ & 7.16 & 12.62 & 16.71 \\
\hline $\mathrm{R} 40 \mathrm{C}$ & 5.53 & 10.08 & 14.49 \\
\hline
\end{tabular}

In mortar mix proportions, in which cement was replaced by sludge in various proportions, a marked increase in compressive strength was observed over time. This increase also manifested after 28 days, even if at a lower rate.

Thus:

- For the R10C mortar, with $10 \%$ cement replaced by sludge, the increase in strength at 28 days compared to that at 7 days is $51.30 \%$ higher, and at 90 days compared to that at 28 days is $28.11 \%$ higher;

- For the R20C mortar, with $20 \%$ cement replaced by sludge, the increase in strength at 28 days compared to that at 7 days is $57.15 \%$ higher, and at 90 days compared to that at 28 days is $2.89 \%$ higher;

- For the R30C mortar, with 30\% cement replaced by sludge, the increase in strength at 28 days compared to that at 7 days is $76.25 \%$ higher, and at 90 days compared to that at 28 days is $32.40 \%$ higher;

- For the R40C mortar, with $40 \%$ cement replaced by sludge, the increase in strength at 28 days compared to that at 7 days is $82.28 \%$ higher, and at 90 days compared to that at 28 days is $43.75 \%$ higher.

At the same time, for standard mortar (RS), the increase in strength at 28 days compared to that at 7 days is $25.93 \%$ higher, and at 90 days compared to that at 28 days is $12.70 \%$ higher.

Compared to the standard mortar, the increase in the amount of cement replaced by sludge entails a decrease in compressive strength. The greatest strength in the studied cases is conferred by the R10C mix proportion, with only $10 \%$ cement replaced. However, it can be seen that only after 90 days does the compressive strength of the R10C mortar $\left(23.88 \mathrm{~N} / \mathrm{mm}^{2}\right)$ reach a value close to that of the standard mortar at 28 days $\left(25.98 \mathrm{~N} / \mathrm{mm}^{2}\right)$.

It is possible to observe that the higher the substitution of cement by sludge, the lower its resistance, this effect may be related to the substitution of the reactive material (cement) by a material with low reactivity (sludge) and may also be related to the water/cement ratio that was not altered as the cement was replaced by sludge (which has a specific surface three times larger than that of cement), implying an increase in porosity and consequently the decrease in resistance [39].

\subsection{Chemical Tests}

The pozzolanic reaction is a chemical reaction that takes place in Portland cement after pozzolanic material addition. The pozzolanic reaction converts a silica-rich precursor, without cementing properties, to a calcium silicate, with good cementing properties [40]. 


\subsubsection{The General Chemical Composition}

The general chemical composition is considered to be one of the parameters that regulates the long-term performance of the mixed cement binder (e.g., the increase in compressive strength over time-previously observed).

ASTM C618 establishes that a pozzolanic material should meet the requirement [41]:

$$
\mathrm{SiO}_{2}+\mathrm{Al}_{2} \mathrm{O}_{3}+\mathrm{Fe}_{2} \mathrm{O}_{3}>70 \%
$$

The content of the main oxides in the chemical composition of CEM II/B-LL (SR EN 197) cement and sludge that was determined by Inductively Coupled Plasma Optical Emission Spectroscopy ICP-OES (SpectroFlame FMD 07, Kleve, Germany), according to SR ISO 11466:1995 and SR EN ISO 11885:2009, is presented in Table 6 [42,43].

Table 6. Chemical compositions of the cement and steel sludge (\%).

\begin{tabular}{ccccccccc}
\hline \multirow{2}{*}{ Material } & \multicolumn{5}{c}{ Oxidic Composition (\%) } \\
\cline { 2 - 7 } & $\mathbf{F e}_{\mathbf{2}} \mathbf{O}_{\mathbf{3}}$ & $\mathbf{S i O}_{\mathbf{2}}$ & $\mathbf{C a O}$ & $\mathbf{A l}_{\mathbf{2}} \mathbf{O}_{\mathbf{3}}$ & $\mathbf{M n O}$ & $\mathbf{M g O}$ & $\mathbf{N a}_{\mathbf{2}} \mathbf{O}$ \\
\hline Cement CEM II/B-LL (SR EN 197) & 3.53 & 16.40 & 68.40 & 4.24 & 0.15 & 2.39 & 0.00 \\
\hline Steel sludge & 17.10 & 0.06 & 14.00 & 0.06 & 0.27 & 0.14 & 0.13 \\
\hline
\end{tabular}

As shown in Table 6, the sum of the percentages of the three oxides in the formula is $17.22 \%$; so, it does not meet the ASTM C618 requirements for a pozzolanic material [41].

In comparison to the oxides in the mixed cement used, aluminum oxide and, in particular, silicon dioxide, should be in a much higher proportion.

\subsubsection{Mineralogical Analysis by X-Ray Diffraction (XRD) of the Sludge and Cement Used}

Figure 2 shows the spectra diagram of steel sludge, using the X-ray diffraction (XRD) system D8 ADVANCE-Da Vinci Design-manufacturer Bruker AXS GmbH (Karlsruhe, Germany).

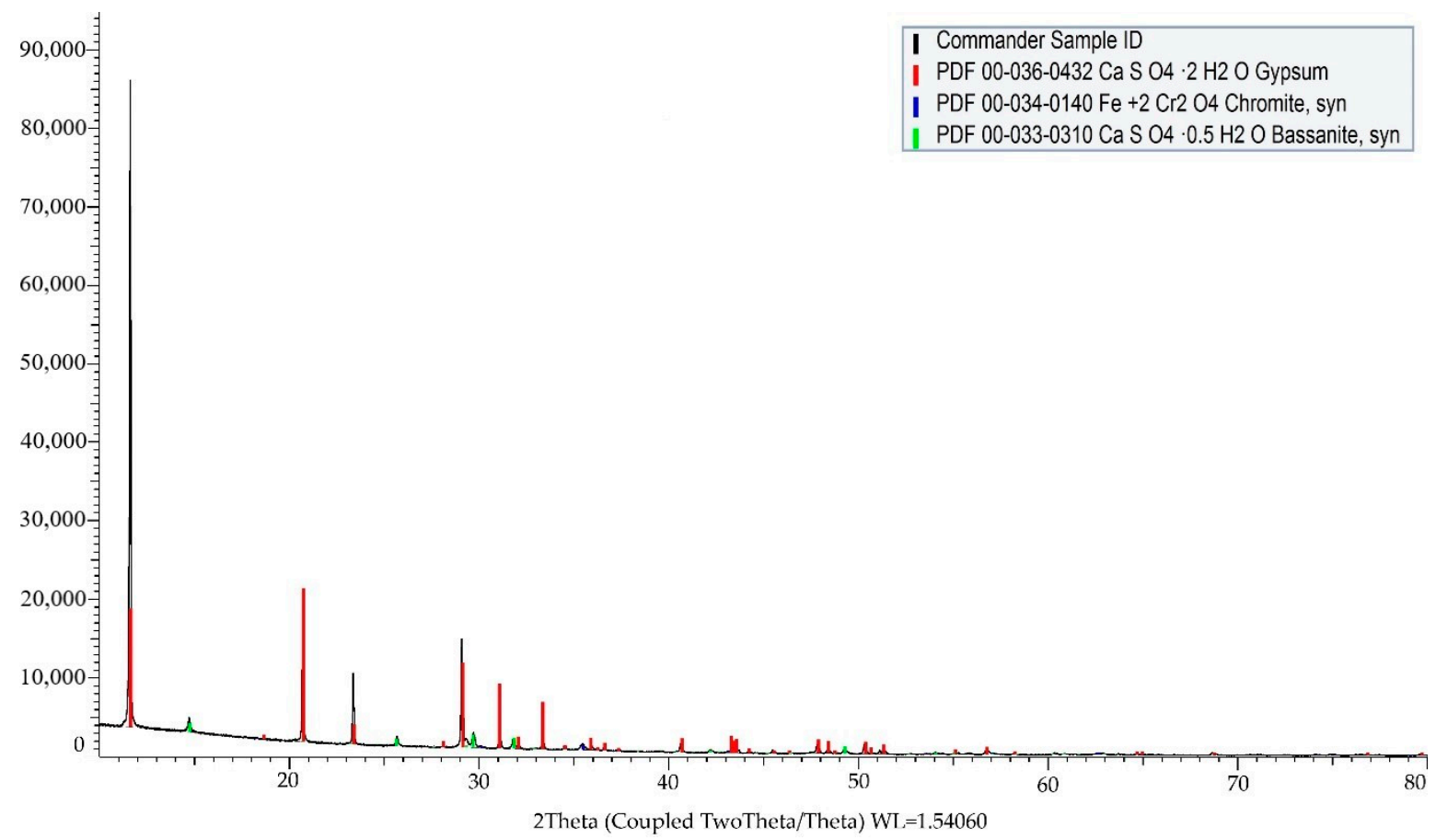

Figure 2. XRD spectra of the steel sludge. 
In the graph in Figure 2, the spectra of the steel sludge components refer to:

- The red spectral line represents gypsum $\mathrm{Ca}\left(\mathrm{SO}_{4}\right) \cdot 2\left(\mathrm{H}_{2} \mathrm{O}\right)$, with a percentage of $83.6 \%$;

- The blue line represents the $\mathrm{Fe}+2 \mathrm{Cr}_{2} \mathrm{O}_{4}$ spectrum-chromite, with a percentage of $4.3 \%$;

- The green line represents the $\mathrm{CaSO}_{4} \cdot 0.5 \mathrm{H}_{2} \mathrm{O}$ spectrum-bassanite, with a percentage of $12.1 \%$.

From the point of view of crystallinity, steel sludge presents $88.9 \%$ crystalline phases and $11.1 \%$ amorphous phases.

Figure 3 presents comparatively the spectra diagram of the chemical components of the cement used.

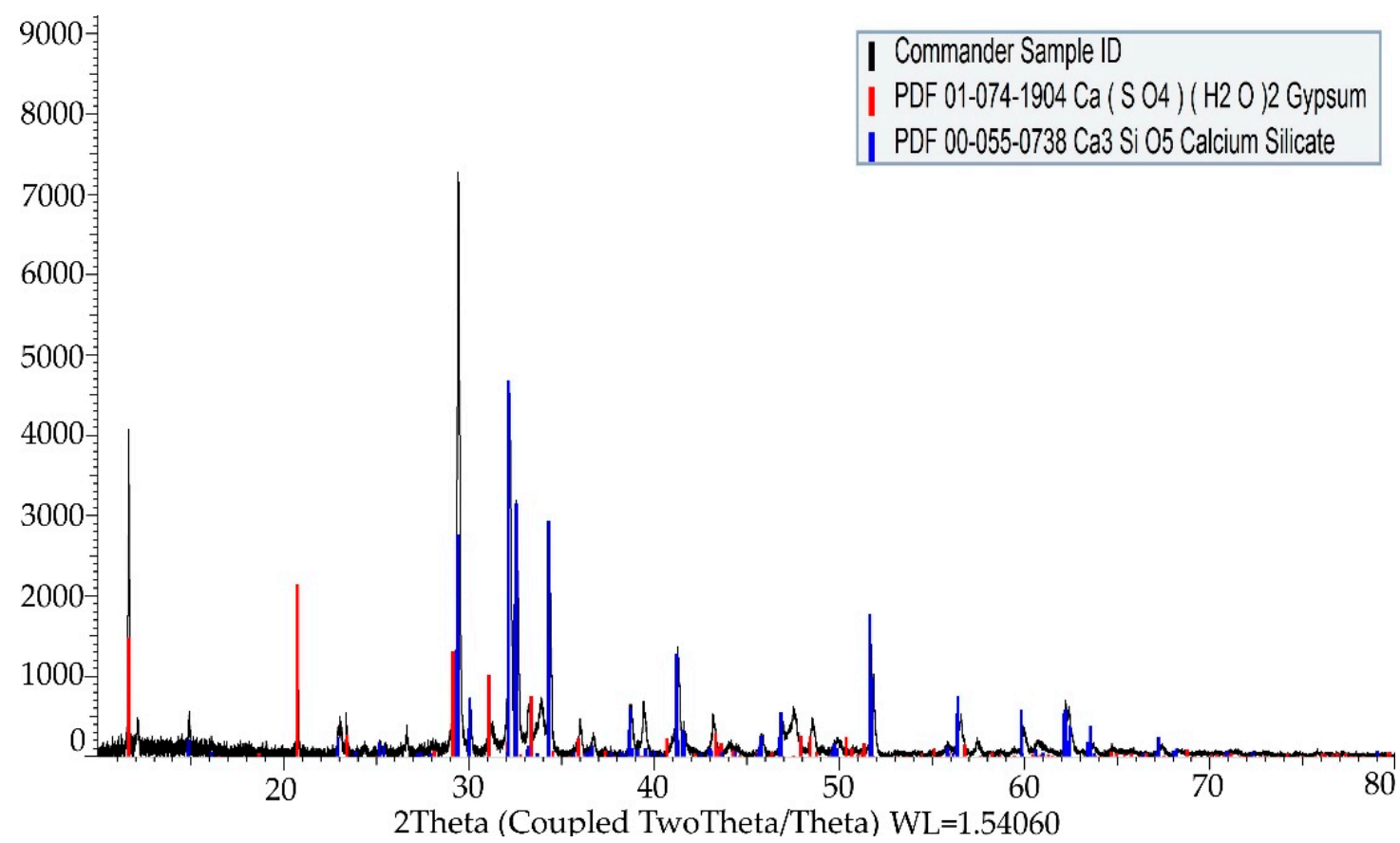

Figure 3. XRD spectra of the CEM II/B-A1 (S-LL) cement.

In the graph in Figure 3, the spectra of the cement components refer to:

- $\quad$ The red spectral line represents gypsum $\mathrm{Ca}\left(\mathrm{SO}_{4}\right) \cdot 2\left(\mathrm{H}_{2} \mathrm{O}\right)$, with a percentage of $20.8 \%$;

- The blue line represents the spectrum of calcium silicate $\mathrm{Ca}_{3} \mathrm{SiO}_{5}$, with a percentage of $79.2 \%$.

Regarding crystallinity, cement presents $99 \%$ crystalline phases and $1 \%$ amorphous phases.

A comparison between the two diagrams shows that:

- From the point of view of crystallinity, both materials present amorphous phases in a low proportion; however, the amorphous phase in the general chemical composition of steel sludge is about 11 times higher than the amorphous phase of cement;

- The percentage of gypsum is lower in the case of cement $(20.8 \%)$ compared to that of the sludge $(83.6 \%)$;

- In addition, in the composition of steel sludge, there is a considerable amount $(12.1 \%)$ of plaster.

- The general chemical composition of cement includes a significant percentage $(79.2 \%)$ of calcium silicate.

According to the literature, the pozzolanic reaction converts a silica-rich precursor, without cementing properties, to a calcium silicate, with good cementing properties [40]. 
As shown by the analyses presented here, the steel sludge does not contain silica, which prevents it from being a pozzolanic material.

The steel sludge could be recycled in the production of red ceramics (bricks and roofing tiles) [44,45], or for the manufacture of mortar or concrete as an aggregate substitute [46]. In this way, the utilization of sludge not only reduces the demand for extraction of natural raw materials, but also solves the disposal problems of waste and safeguards nature.

\section{Conclusions}

The main purpose of this study was to investigate using sludge as a possible addition to ordinary Portland cement in order to obtain a more sustainable and durable cementitious material.

The most important conclusions that can be drawn from this study are the following:

- The sludge particles have a large specific surface-almost three times larger than that of the cement particles;

- A comparison of the two spectra shows that, although in both materials the amorphous phase represents a low proportion, the amorphous phase in the general chemical composition of steel sludge is about 11 times higher than the amorphous phase of cement;

- In the general chemical composition of cement, there is a significant percentage (79.2\%) of calcium silicate, while steel sludge does not contain silica, which prevents it from being a pozzolanic material;

- On the other hand, the requirement concerning the sum of oxides in the chemical composition for a material to be pozzolanic, according to ASTM C618, namely $\mathrm{SiO}_{2}+$ $\mathrm{Al}_{2} \mathrm{O}_{3}+\mathrm{Fe}_{2} \mathrm{O}_{3}>70 \%$, is not met by steel sludge, for which this sum is only $17.22 \%$;

- From the point of view of compressive strength, the mortar prepared with sludge as a cement substitute presents an increase over time, even after 28 days. The increase in the amount of cement replaced by sludge entails a decrease in the compressive resistance. The greatest strength in the studied cases is that of the R10C mix proportion, with only $10 \%$ cement replaced.

Therefore, it can be concluded that the studied steel sludge does not have pozzolanic properties.

Author Contributions: Conceptualization, C.A., D.L.M. and D.-A.I.-V.; methodology, C.A.; software, C.A.; validation, C.A.; investigation, C.A.; resources, C.A., D.L.M. and D.-A.I.-V.; data curation, C.A.; writing-original draft preparation, C.A.; writing-review and editing, C.A., D.L.M. and D.-A.I.-V.; project administration, C.A.; funding acquisition, C.A. All authors have read and agreed to the published version of the manuscript.

Funding: This research was funded by the Technical University of Cluj-Napoca, Internal competition for Research/Development/Innovation-grant number 14514, C.I. type 1.1-T5.

Data Availability Statement: The data presented in this study are available on request from the corresponding author. The data are not publicly available due to the Confidentiality and Nondisclosure Agreement with the funders.

Conflicts of Interest: The authors declare no conflict of interest.

\section{References}

1. Rujanu, M.; Diaconu, L.I.; Babor, D.; Plian, D.; Diaconu, A.C. Study on the optimization of some cement based mixing binders' characteristics. Procedia Manuf. 2018, 22, 114-120. [CrossRef]

2. Amin, M.N.; Murtaza, T.; Shahzada, K.; Khan, K.; Adil, M. Pozzolanic Potential and Mechanical Performance of Wheat Straw Ash Incorporated Sustainable Concrete. Sustainability 2019, 11, 519. [CrossRef]

3. Fořt, J.; Šál, J.; Žák, J.; Černý, R. Assessment of Wood-Based Fly Ash as Alternative Cement Replacement. Sustainability 2020, 12, 9580. [CrossRef]

4. Menéndez, E.; Sanjuán, M.Á.; García-Roves, R.; Argiz, C.; Recino, H. Sustainable and Durable Performance of Pozzolanic Additions to Prevent Alkali-Silica Reaction (ASR) Promoted by Aggregates with Different Reaction Rates. Appl. Sci. 2020, 10, 9042. [CrossRef] 
5. Yagüe, S.; González Gaya, C.; Rosales Prieto, V.; Sánchez Lite, A. Sustainable Ecocements: Chemical and Morphological Analysis of Granite Sawdust Waste as Pozzolan Material. Materials 2020, 13, 4941. [CrossRef] [PubMed]

6. Karim, M.R.; Hossain, M.M.; Khan, M.N.N.; Zain, M.F.M.; Jamil, M.; Lai, F.C. On the Utilization of Pozzolanic Wastes as an Alternative Resource of Cement. Materials 2014, 7, 7809-7827. [CrossRef] [PubMed]

7. Memon, S.A.; Wahid, I.; Khan, M.K.; Tanoli, M.A.; Bimaganbetova, M. Environmentally Friendly Utilization of Wheat Straw Ash in Cement-Based Composites. Sustainability 2018, 10, 1322. [CrossRef]

8. Yagüe García, S.; González Gaya, C. Reusing Discarded Ballast Waste in Ecological Cements. Materials 2019, 12, 3887. [CrossRef]

9. Sumathi, S.; Chai, S.P.; Mohamed, A.R. Utilization of oil palm as a source of renewable energy in Malaysia. Renew. Sustain. Energy Rev. 2008, 12, 2404-2421. [CrossRef]

10. Mohammad, I.; Mohamed, E.I.; Bala, M. Influence of elevated temperatures on physical and compressive strength properties of concrete containing palm oil fuel ash. Constr. Build. Mater. 2011, 25, 2358-2364.

11. Aciu, C.; Roman, C.; Iluţiu-Varvara, D.A.; Puia, C.; Cadar, O. Plastering mortar with antibacterial and antifungal properties. Rom. J. Mater. 2016, 46, 160-166.

12. Alnahhal, M.F.; Alengaram, U.J.; Jumaat, M.Z.; Alqedra, M.A.; Mo, K.H.; Sumesh, M. Evaluation of Industrial By-Products as Sustainable Pozzolanic Materials in Recycled Aggregate Concrete. Sustainability 2017, 9, 767. [CrossRef]

13. Shagñay, S.; Ramón, L.; Fernández-Álvarez, M.; Bautista, A.; Velasco, F.; Torres-Carrasco, M. Eco-Efficient Hybrid Cements: Pozzolanic, Mechanical and Abrasion Properties. Appl. Sci. 2020, 10, 8986. [CrossRef]

14. Moon, J.; Taha, M.M.R.; Youm, K.-S.; Kim, J.J. Investigation of Pozzolanic Reaction in Nanosilica-Cement Blended Pastes Based on Solid-State Kinetic Models and 29Si MAS NMR. Materials 2016, 9, 99. [CrossRef]

15. Yagüe, S.; Sánchez, I.; de la Villa, R.V.; García-Giménez, R.; Zapardiel, A.; Frías, M. Coal-Mining Tailings as a Pozzolanic Material in Cements Industry. Minerals 2018, 8, 46. [CrossRef]

16. Liguori, B.; Aprea, P.; Gennaro, B.; Iucolano, F.; Colella, A.; Caputo, D. Pozzolanic Activity of Zeolites: The Role of Si / Al Ratio. Materials 2019, 12, 4231. [CrossRef] [PubMed]

17. Sičáková, A.; Špak, M. The Effect of a High Amount of Micro-Fillers on the Long-Term Properties of Concrete. Materials 2019, 12, 3421. [CrossRef] [PubMed]

18. CE-SPIRE-03-2018. Innovative and Efficient Solution, Based on Modular, Versatile, Smart Process Units for Energy and Resource Flexibility in Highly Energy Intensive Processes. Available online: https:/ / www.spire2030.eu/cirmet (accessed on 29 January 2021).

19. DIGISER++ Project. Innovative Waste Recycling for the Copper Industry. Available online: https://www.digiser.tech/ (accessed on 29 January 2021).

20. Gao, D.; Wang, F.-P.; Wang, Y.-T.; Zeng, Y.-N. Sustainable Utilization of Steel Slag from Traditional Industry and Agriculture to Catalysis. Sustainability 2020, 12, 9295. [CrossRef]

21. Tang, Z.; Ding, X.; Yan, X.; Dong, Y.; Liu, C. Recovery of Iron, Chromium, and Nickel from Pickling Sludge Using Smelting Reduction. Metals 2018, 8, 936. [CrossRef]

22. Ahmadi, M.; Bohlool, F.; Babaei, A.A.; Teymouri, P. Characteristics and disposal options of sludge from a steel mill wastewater treatment plant. J. Adv. Environ. Health Res. 2013, 1, 112-119.

23. Abdul Kadir, A.; Abd Jalil, M.R.; Al Bakri Abdullah, M.M. Properties of Steel Mill Sludge Waste Incorporated in Fired Clay Brick. Mater. Sci. Forum. 2016, 857, 358-362. [CrossRef]

24. Brand, A.S.; Fanijo, E.O. A Review of the Influence of Steel Furnace Slag Type on the Properties of Cementitious Composites. Appl. Sci. 2020, 10, 8210. [CrossRef]

25. Iluţiu-Varvara, D.A.; Aciu, C.; Tintelecan, M.; Sas-Boca, I.M. Assessment of Recycling Potential of the Steel Mill Scale in the Composition of Mortars for Sustainable Manufacturing. Procedia Manuf. 2020, 46, 131-135. [CrossRef]

26. Sheikibrahim, K.; Sathish, S.; Mohammed Fahad, A.S.; Sathish Sharma, A.; Karthika, H.; Shanmuganathan, N. Ground Granulated Blast Furnace Slag (GGBS or GGBFS) and Flyash in Concrete. Int. Res. J. Eng. Technol. 2018, 5, 266-270.

27. Suresh, D.; Nagaraju, K. Ground Granulated Blast Slag (GGBS) in Concrete-A review. IOSR J. Mech. Civ. Eng. 2015, 12, 76-82.

28. Zulu, B.A.; Miyazawa, S.; Nito, N. Properties of Blast-Furnace Slag Cement Concrete Subjected to Accelerated Curing. Infrastructures 2019, 4, 69. [CrossRef]

29. Voit, K.; Zeman, O.; Janotka, I.; Adamcova, R.; Bergmeister, K. High-Durability Concrete Using Eco-Friendly Slag-Pozzolanic Cements and Recycled Aggregate. Appl. Sci. 2020, 10, 8307. [CrossRef]

30. Nurul, H.R.; Mohammad, I.; Zaiton, A.M.; Seyedmojtaba, G.; Bala, M. Performance of steel slag and steel sludge in concrete. Constr. Build. Mater. 2016, 104, 16-24.

31. Wang, G. Determination of the expansion force of coarse steel slag aggregate. Constr. Build. Mater. 2010, 24, 1961-1966. [CrossRef]

32. SR EN 197-1: Cement. Part 1: Composition, Specification and Conformity Criteria for Usual Cements; European Committee for Standardization: Brussels, Belgium, 2011.

33. SR EN 196-6: Methods of Testing Cement. Part 6: Determination of Fineness; European Committee for Standardization: Brussels, Belgium, 2019.

34. SR EN 196-1: Methods of Testing Cement. Part 1: Determination of Strength; European Committee for Standardization: Brussels, Belgium, 2016. 
35. SR EN 12457-2: Characterization of Waste. Leaching. Compliance Test for Leaching of Granular Waste Materials and Sludges. One Stage Batch Test at a Liquid to Solid Ratio of $10 \mathrm{l} / \mathrm{kg}$ for Materials with Particle Size below $4 \mathrm{~mm}$ (without or with Size Reduction); European Committee for Standardization: Brussels, Belgium, 2002.

36. ISO. Water Quality. Application of Inductively Coupled Plasma Mass Spectrometry (ICP-MS)—Part 2: Determination of Selected Elements Including Uranium Isotopes; International Organization for Standardization: London, UK, 2016.

37. Council Decision of 19 December 2002 Establishing Criteria and Procedures for the Acceptance of Waste at Landfills Pursuant to Article 16 of and Annex II to Directive 1999/31/EC. Available online: https:/ / eur-lex.europa.eu/legal-content/EN/TXT/PDF/ ?uri=CELEX:32003D0033\&from=RO (accessed on 12 February 2021).

38. Benezet, J.C.; Benhassaine, A. Grinding and pozzolanic reactivity of quartz powders. Powder Technol. 1999, 105, 167-171. [CrossRef]

39. Dossena, M.H.; Bevilaqua, D.; Silva, L.L.; Fiori, M.A.; Batiston, E.R.; Muneron de Mello, J.M. Evaluation of Mechanical Properties of Sealing Mortar with Partial Replacement of Portland Cement by Stone Crusher Waste. Mater. Res. 2019, 22, e20180868. [CrossRef]

40. Massazza, F. Pozzolana and pozzolanic cements. In Lea's Chemistry of Cement and Concrete, 4th ed.; Butterworth-Heinemann: Oxford, UK, 2003; pp. 471-635.

41. ASTM C618-19. Standard Specification for Coal Fly Ash and Raw or Calcined Natural Pozzolan for Use in Concrete; ASTM International: West Conshohocken, PA, USA, 2019; Available online: www.astm.org (accessed on 20 February 2021).

42. SR ISO 11466: Soil Quality. Extraction of Trace Elements Soluble in Aqua Regia; International Organization for Standardization: London, UK, 1995.

43. SR EN ISO 11885: Water quality. Determination of Selected Elements by Inductively Coupled Plasma Optical Emission Spectrometry (ICP-OES); International Organization for Standardization: London, UK, 2009.

44. Andrade, P.M.; Vieira, C.M.F.; Monteiro, S.M.; Venilli, J.F. Recycling of steel sludge into red ceramic. Mater. Sci. Forum 2006, 530-531, 544-549. [CrossRef]

45. Vieira, C.M.F.; Andrade, P.M.; Maciel, G.S.; Vernilli, F.; Monteiro, S.N. Incorporation of fine steel sludge waste into red ceramic. Mater. Sci. Eng. 2006, 427, 142-147. [CrossRef]

46. Alwaeli, M.; Gołaszewski, J.; Niesler, M.; Pizoń, J.; Gołaszewska, M. Recycle option for metallurgical sludge waste as a partial replacement for natural sand in mortars containing CSA cement to save the environment and natural resources. J. Hazard. Mater. 2020, 398, 123101. [CrossRef] [PubMed] 